\title{
The Management and Use of Research-related Information by a Selection of Research-intensive Universities in South Africa
}

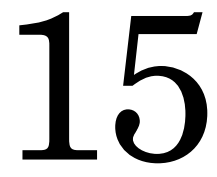

\author{
Jan Botha and Maryke Hunter-Hüsselmann
}

\section{Introduction}

Knowledge production through research is generally regarded as one of the core functions of universities. If Institutional Research (IR) is understood as research aimed at supporting the decision-making processes of universities across the full range of their functions, it follows that decision support in the area of knowledge production and research management should also be seen as a form of IR. This a specialised and highly developed professional practice in research-intensive universities.

Universities across the world nowadays have dedicated IR offices responsible for a wide range of tasks, including the coordination of strategic planning, quality assurance, student life-cycle surveys, statistical analysis for internal and external reporting, and resource allocation and planning (Chirikov 2013:459). In Europe, for example, IR is associated with higher education policy and management studies at a macro level (national and systemwide policies) (Kehm 2015:61-62). The activities currently most commonly associated with IR in the United States of America encompass (a) external and internal reporting and administrative policy analysis, (b) strategic planning, enrolment planning, financial management, and (c) learning outcome assessments, programme reviews, accountability, accreditation, and institutional effectiveness (Volkwein 2008 and Volkwein et al. 2012). It is noteworthy that these authors do not specifically include institutional research aimed at decision support in the area of knowledge production and research management in their definitions of IR. Furthermore, an analysis of the proceedings of the Annual Conferences of the Southern African Association for Institutional Research (SAAIR) from 1994 to 2015 (see Chapter 3 of this book) revealed that only $4 \%$ of the papers were related to the research function of universities.

The absence of a focus on the research function of universities in the activities commonly associated with IR can be ascribed to its historical development (Reichard 2012). Academic leaders responsible for research management expect high quality institutional research to support decision making in their portfolios. The research management functions related to the management and use of research data and information are usually based in the university's research support office (often called Research Development Unit or Research Administration) and not in the IR Office. Our argument will follow that research support offices employ research administrators and managers who function as IR practitioners in the 
sense that these individuals extract, analyse, and disseminate research-related information (RRI) with the aim of adding value to the decision-making processes of universities.

Our research question was to determine whether the management and use of RRI by research support offices can be seen as part of the broader IR activities of universities and, if so, to describe how research support offices function as custodians and providers of the RRI that is critical for institutional decision making.

The data on which we base the results reported on in this chapter were gathered through interviews with the research directors of the six universities selected for this study. We limited our study to focus on the six South African universities that have been the most productive in research output during the last decade or so (since 2005), namely Rhodes University, the University of Cape Town, the University of KwaZulu-Natal, the University of Pretoria, Stellenbosch University and the University of the Witwatersrand. There are, of course, other universities in South Africa with impressive research outputs and wellfunctioning research support offices. However, in our selection of these six institutions only their research performance (in terms of outputs) was considered, with the assumption that those universities with the best performance would have dynamic research support offices from which valuable insights could be gained. The interviews with the research directors have confirmed the validity of that assumption.

From our interviews, it became clear that the management of RRI has become complex and multi-faceted, and that the uses of this type of information have expanded and changed significantly in recent years.

In this chapter, we begin by commenting on the characteristics of new scenarios in research management and their implications for the management and the uses of RRI. We then present a description of the different categories of RRI captured by the six universities and we map the institutional role players responsible for the different categories of RRI. We analyse these categories in terms of Terenzini's (1993 and 2013) distinction of three tiers of IR (or organisational intelligence), namely technical intelligence, issues intelligence, and contextual intelligence. We illustrate by means of examples reported by the research directors how the different categories of RRI are used in all three organisational intelligence tiers. This is followed by a discussion of the interventions required to develop the skills of institutional researchers employed in research support offices to enrich and add value to RRI to serve a range of traditional and new users.

\section{Changes in research management}

Calderon and Webber maintain that "IR practitioners are now playing an active and visionary role in developing strategy and assessing the long-term positioning for institutions and national systems" (2015:5). In their study of institutional positioning in higher education, Fumasoli and Huisman (2013) explain that the institutional positioning of universities reflects their strategic intent or their capability to locate themselves in a favourable niche. Institutional positioning can be seen as the link pin between the higher education institution and the higher education system within the broader environment. Like other organisations, universities construct their identity by self-reflecting, by making choices and by confronting and interacting with others 
in the environment. Distinctiveness is sought and a competitive advantage is achieved by the development of a unique profile that competitors cannot replicate. Fumasoli and Huisman (2013) distinguish between different dimensions of institutional positioning: (a) it can be portrayed as a balance between deliberateness (managerial purposiveness) and emergence (environmental influences) and (b) it entails a trade-off between differentiation (universities make themselves different to elude competition) and compliance (universities strive to abide by the rules in their search for legitimacy). The outcome of the institutional positioning process is that a university finds a particular niche.

The changes in the higher education environment in recent decades have been well documented (Altbach, Reisberg and Rumbly, 2010), summarised by Hazelkorn (2015:3ff) under four headings: (a) transition to knowledge-intensive economies, (b) demographic pressures and the global pursuit of talent, (c) criticality of higher education to the economy and society and the importance of research universities, and (d) informed student choice and consumerist attitudes towards higher education. Research universities are at the pinnacle of the academic system and form an important driver of the global knowledge network. Research production has become extremely important, not just to the prestige of individual institutions, but also to national development agendas (Altbach et al. 2010:35). In this highly competitive environment, universities must position themselves and their research identities.

These developments confront the IR practitioners located in research support offices and the senior officials responsible for research management with a range of new challenges. It is therefore not surprising that the research management function, including the management and use of RRI, has undergone major changes. The role of research managers has changed from primarily providing administrative support towards an active and visionary role in the positioning of their universities (Shelly 2010). Although research management is a relatively new function in South African higher education institutions, the space that it occupies (although sometimes blurred), has become part of the strategic functioning of institutions.

The area of research management and administration is a relatively under-researched area in South Africa. Studies done in the United Kingdom, for example, do, however, suggest a correlation between the issues and trends that are discernible in other countries and the experiences at South African universities, such as the dynamics and tension between academic units and support and administrative units; the roles, responsibilities and identities of support and administrative staff; and the professionalisation of these functions (see, for example, Carter and Langley 2009; Deem 2010; Shelley 2010).

Whitchurch $(2007 ; 2008 ; 2009 ; 2013)$ has written extensively on the new professional identities being formed in higher education. She uses the word "professional managers" to describe a "heterogeneous group of people", including "manager; administrator; nonacademic staff; academic-related staff; professional staff; support staff" (2007:2). She notes a lack of understanding by academic staff and even by some senior managers in HEls of the roles and identities of professional staff, since many of them also have academic credentials, a teaching or research background, expertise in dealing with institutional initiatives, and also undertake quasi-academic functions. In the case of research management, such quasiacademic functions can include the presentation of skills-development workshops for researchers, the facilitation of interdisciplinary research groupings, etc. Furthermore, research 
managers located in research support offices often exercise an academic management role (Whitchurch, 2008:379). Drawing on a study of 54 professional managers in the United Kingdom, Australia and the United States, Whitchurch (2008:377) identifies various distinct roles of professional managers, including a number of generalist roles (e.g. student services, departmental management) and a number of specialised roles (e.g. finance and human resources). She uses the notion of a "niche" function to refer to the work of specialists responsible for functions such as research management and quality assessment. Whitchurch proposes the term "blended professionals" to refer to professional staff "who have mixed backgrounds and portfolios, comprising elements of both professional and academic activity" (2008:377). These blended professionals operate in what she calls a "third space" between the professional and academic domains.

Our interviews with the research directors of the six research-intensive universities confirm that this also holds true for South African universities. Research managers work in a "third space". The specific form it takes on depends on the institutional culture and the intensity of the drive for research excellence in a particular university.

Authors such as Langley and Ofosu (2007), Carter and Langley (2009), Schützenmeiser (2010) and Theron (2013) have identified the following activities in current research management practices: co-responsible with executive management to set research strategy, to develop research-related policies and to decide on research themes at institutional, faculty and individual levels; research environment scanning, trends analysis and the gathering, analysis and dissemination of intelligence; benchmarking and the calculation and analysis of research metrics; development of partnerships, pre-award assessment of the skills of researchers applying for grants, researching and applying costing methodologies and budget control; guiding internal peer review processes; contract negotiation; post-award management and adherence to sponsor terms and conditions; various audits; networking with sponsors and being up to date with their requirements; organisational portfolio management and reporting; project management of large contracts and bids; research ethics and integrity; international research programmes and partnerships; knowledge transfer and intellectual property; spin outs and commercialisation; consultancy; business systems and accounting; production, management, use, promotion and showcasing of research outputs, including formal and informal reports; and, finally, monitoring compliance and risk areas and developing and maintaining corporate systems and administrative mechanisms for the support and automation of processes, and the capturing and provision of information which underpins all of the other areas.

While most, if not all, of these activities are already prevalent in research-intensive universities in South Africa, a survey of research managers based in Africa and the Caribbean indicates that the profession is often still seen as an emerging field in Southern Africa. In some institutions, research administrators and managers are still grappling with the establishment of the research support function in their institutions. It has been established, however, that in many higher education institutions "research managers are expected to fulfil high demanding roles with very few resources" (Research Africa 2013:2).

Research management is developing into a profession and has become a critical success factor in the establishment and growth of research cultures in environments with different 
contextual challenges and opportunities. Institutional research on the management and use of RRI forms in many respects the basis of all these activities.

The next section is therefore devoted to a discussion of a definition of RRI. We also present our findings on the custodians and systems used for this type of information in the selected South African universities.

\section{Research-related information}

\section{Defining research-related information}

In a recent report on the management of RRI in African universities, the Association of Commonwealth Universities (2015:1) defines research information as "the administrative information surrounding the research outputs of an institution. This usually encompasses publications, projects, grants, and professional activities".

Considering the broad range of responsibilities of research managers discussed in the previous section, and the related research information required, this definition has to be broadened to include, as Lourens (2012) has indicated, information of a much more strategic nature that can contribute to the decision-making processes of institutions.

This was confirmed by our interviews with research directors at a selection of researchintensive universities in South Africa:

“... institutional research refers, first of all, to a broader process of acquiring data, analysing data, using data for the benefit of the university strategic planning. So obviously research-related data is a component of that." (Interview 1)

Schützenmeiser (2010) notes that although the term "knowledge management" (KM) has not really featured in the literature on research management, KM has become an increasingly important feature of what is being done in research support offices. He refers to the work of Shahom and Perry (2009) and Atkinson et al. (1998) when he argues that "strategic knowledge management" is a responsibility of research managers (2010:15). This includes, in the South African context, for example, the communication and marketing of research findings for the purpose of the creation of more funds, the creation of, for example, centres of excellence, where a group of experts receive funding specifically to work together on a particular research area. It can also include knowledge on where the institutions' core competencies lie or their weaknesses, for that matter, and it informs the research performance of individual researchers.

\section{Custodians and categories of research related information}

In the previous section we reported a list of research management activities as identified by a number of authors. We now focus on the types of RRI that the six study interviewees have identified as being in use in their research support offices (listed in the first column of Table 1 below). 
It is important to distinguish between the processes related to the information about the research activities and the information systems used for the management of this information. We analysed the dynamics of the management of RRI in the six universities. For this purpose, we distinguished between the curator of information and process owner (responsible for definitions, processes to capture information, data quality, processes to update information, reporting the information) and the curator of information system and database (responsible for the development and maintenance of the database and technical system, software, information architecture, interoperability, data integration).

Table 1: Categories and custodianship of RRI in six South African research-intensive universities Categories and custodianship of research-related information in six South African universities

\begin{tabular}{|c|c|c|c|}
\hline Types of RRI & Curator of Information & $\begin{array}{l}\text { Curator of Information } \\
\text { System }\end{array}$ & Name of system \\
\hline $\begin{array}{l}\text { Information on researchers } \\
\text { (HR information) }\end{array}$ & $\begin{array}{l}\text { HR department supported } \\
\text { by ICT department, some } \\
\text { collaboration with Research } \\
\text { Support Office }\end{array}$ & $\begin{array}{l}\text { ICT department in } \\
\text { partnership with HR }\end{array}$ & $\begin{array}{l}\text { Mostly enterprise systems, } \\
\text { e.g. Oracle-HR, SAP-HR, } \\
\text { or homegrown systems } \\
\text { (e.g. Protea) }\end{array}$ \\
\hline $\begin{array}{l}\text { Publication outputs (journal } \\
\text { articles, book chapters, } \\
\text { conference proceedings) }\end{array}$ & Research Support Office & $\begin{array}{l}\text { ICT department or } \\
\text { Research Support Office in } \\
\text { partnership with an external } \\
\text { service provider }\end{array}$ & $\begin{array}{l}\text { Research Administrator, } \\
\text { IRMA Publications, or } \\
\text { Thomson Reuters Converis, } \\
\text { Protea, InfoEd }\end{array}$ \\
\hline $\begin{array}{l}\text { Masters and doctoral student } \\
\text { information (enrolments, } \\
\text { graduations) }\end{array}$ & $\begin{array}{l}\text { Registrar's Office (in } \\
\text { cooperation with Faculty/ } \\
\text { College Offices) }\end{array}$ & $\begin{array}{l}\text { ICT department in } \\
\text { partnership with } \\
\text { Registrar's Office }\end{array}$ & $\begin{array}{l}\text { Oracle's PeopleSoft Campus } \\
\text { Solutions, Protea, IRMA, or } \\
\text { homegrown systems }\end{array}$ \\
\hline NRF-rated researchers & Research Support Office & Research Support Office & $\begin{array}{l}\text { Excel spreadsheets, } \\
\text { Thomson Reuters Converis }\end{array}$ \\
\hline $\begin{array}{l}\text { Post-doctoral research } \\
\text { fellows }\end{array}$ & $\begin{array}{l}\text { Research Support Office } \\
\text { or Faculty/College Offices } \\
\text { \& Registrar's Office, or } \\
\text { HR department }\end{array}$ & $\begin{array}{l}\text { ICT department in } \\
\text { partnership with RSO or } \\
\text { Registrar's Office }\end{array}$ & $\begin{array}{l}\text { Excel spreadsheets or } \\
\text { Oracle's PeopleSoft } \\
\text { Campus Solutions }\end{array}$ \\
\hline $\begin{array}{l}\text { Funding and grants: Internal } \\
\text { university grants }\end{array}$ & $\begin{array}{l}\text { Research Support Office or } \\
\text { Faculty/College Offices }\end{array}$ & $\begin{array}{l}\text { ICT department in } \\
\text { partnership with Research } \\
\text { Support Office and the } \\
\text { Finance Department }\end{array}$ & $\begin{array}{l}\text { Oracle's PeopleSoft Campus } \\
\text { Solutions, InfoEd or a } \\
\text { homegrown finance system } \\
\text { (in some cases migrating to } \\
\text { the Kuali Finance System) }\end{array}$ \\
\hline Funding and grants: national & $\begin{array}{l}\text { Research Support Office, } \\
\text { in partnership with } \\
\text { Legal Services }\end{array}$ & $\begin{array}{l}\text { ICT department in } \\
\text { partnership with Research } \\
\text { Support Office and } \\
\text { Finance Department and } \\
\text { Legal Services }\end{array}$ & $\begin{array}{l}\text { A home-grown finance } \\
\text { system or ImageNow and } \\
\text { Excel spreadsheets, Oracle } \\
\text { Finance, or InfoEd }\end{array}$ \\
\hline $\begin{array}{l}\text { Funding and grants: } \\
\text { international }\end{array}$ & Research Support Office & $\begin{array}{l}\text { ICT department in } \\
\text { partnership with Research } \\
\text { Support Office and Finance } \\
\text { Department and Registrar's } \\
\text { Office and Legal Services }\end{array}$ & $\begin{array}{l}\text { A finance system } \\
\text { (sometimes a home-grown } \\
\text { system), ImageNow, } \\
\text { Excel spreadsheets, or } \\
\text { Oracle Finance }\end{array}$ \\
\hline
\end{tabular}


(Table 1 continued)

\begin{tabular}{|c|c|c|c|}
\hline Types of RRI & Curator of Information & $\begin{array}{c}\text { Curator of Information } \\
\text { System }\end{array}$ & Name of system \\
\hline $\begin{array}{l}\text { Research Contracts (number, } \\
\text { source of funding, partners, } \\
\text { duration, agreement details, } \\
\text { conditions, outputs, legal } \\
\text { clearance) }\end{array}$ & Research Support Office & $\begin{array}{l}\text { ICT department (in terms } \\
\text { of the enterprise system) } \\
\text { or Research Contracts \& } \\
\text { Intellectual Property Services } \\
\text { (RCIPS) Department or } \\
\text { Legal Services }\end{array}$ & $\begin{array}{l}\text { IRMA Contracts \& Grants } \\
\text { (migrating to Thomson } \\
\text { Reuters Converis), } \\
\text { ImageNow, or a home- } \\
\text { grown contract management } \\
\text { system based on Excel } \\
\text { spreadsheets }\end{array}$ \\
\hline $\begin{array}{l}\text { Facilities and equipment } \\
\text { (buildings, labs, register of } \\
\text { expensive equipment) }\end{array}$ & $\begin{array}{l}\text { Facilities department / } \\
\text { Properties \& Services (P\&S) } \\
\text { Department / in cooperation } \\
\text { with faculties/colleges }\end{array}$ & External service provider & $\begin{array}{l}\text { A commercial facilities } \\
\text { management system (EAM) } \\
\text { or home-grown systems }\end{array}$ \\
\hline $\begin{array}{l}\text { Ethics approvals / } \\
\text { Information related to } \\
\text { research integrity }\end{array}$ & Research Support Office & $\begin{array}{l}\text { ICT department (in some } \\
\text { cases in partnership with } \\
\text { NRF RIMS team) }\end{array}$ & $\begin{array}{l}\text { InfoEd or various systems } \\
\text { including MS Access, IRMA } \\
\text { or Exce/ spreadsheets }\end{array}$ \\
\hline $\begin{array}{l}\text { Intellectual Property and } \\
\text { Technology Transfer }\end{array}$ & $\begin{array}{l}\text { Innovation Services Office } \\
\text { (Inqubate/Innovus, or } \\
\text { Research Contracts \& } \\
\text { Intellectual Property Services } \\
\text { (RCIPS) or the Institutional } \\
\text { Enterprise Outfit }\end{array}$ & $\begin{array}{l}\text { ICT department (in } \\
\text { partnership with NRF } \\
\text { RIMS team in cooperation } \\
\text { with Legal Services) or } \\
\text { Institutional Enterprise Outfit }\end{array}$ & $\begin{array}{l}\text { Info-Ed or a home-grown } \\
\text { system using MS Access } \\
\text { or Excel }\end{array}$ \\
\hline $\begin{array}{l}\text { Information on focus areas, } \\
\text { initiatives, flagships, Centres } \\
\text { of Excellence, Research } \\
\text { Chairs) }\end{array}$ & $\begin{array}{l}\text { Various custodians, including } \\
\text { Research Support Office and } \\
\text { Institutional Research and } \\
\text { Planning Office }\end{array}$ & $\begin{array}{l}\text { ICT department in } \\
\text { cooperation with various } \\
\text { different offices, including the } \\
\text { Research Support Office }\end{array}$ & $\begin{array}{l}\text { Various systems, including } \\
\text { home-grown systems } \\
\text { developed by the Research } \\
\text { Support Office }\end{array}$ \\
\hline $\begin{array}{l}\text { Partnerships, research } \\
\text { collaborators }\end{array}$ & $\begin{array}{l}\text { Various custodians, including } \\
\text { Research Support Office } \\
\text { and International Academic } \\
\text { Programmes Office (IAPO) }\end{array}$ & $\begin{array}{l}\text { ICT department in } \\
\text { cooperation with various } \\
\text { offices, including the } \\
\text { Research Support Office }\end{array}$ & $\begin{array}{l}\text { Various systems including } \\
\text { ImageNow, or home-grown } \\
\text { systems developed by the } \\
\text { Research Support Office or } \\
\text { by the International Academic } \\
\text { Programmes Office }\end{array}$ \\
\hline $\begin{array}{l}\text { Strategic Management } \\
\text { Indicators }\end{array}$ & $\begin{array}{l}\text { Various custodians, including } \\
\text { Institutional Research and } \\
\text { Planning Office }\end{array}$ & $\begin{array}{l}\text { ICT department in } \\
\text { cooperation with various } \\
\text { offices, including the } \\
\text { Institutional Research and } \\
\text { Planning Office }\end{array}$ & $\begin{array}{l}\text { Various systems, including } \\
\text { Business Objects and others }\end{array}$ \\
\hline Benchmarking information & $\begin{array}{l}\text { Various custodians, including } \\
\text { Institutional Research and } \\
\text { Planning Office }\end{array}$ & $\begin{array}{l}\text { ICT department in } \\
\text { cooperation with various } \\
\text { offices, including the } \\
\text { Institutional Research and } \\
\text { Planning Office }\end{array}$ & $\begin{array}{l}\text { Various systems, including } \\
\text { Business Objects and others }\end{array}$ \\
\hline Rankings information & $\begin{array}{l}\text { Various custodians, including } \\
\text { Institutional Research and } \\
\text { Planning Office }\end{array}$ & $\begin{array}{l}\text { ICT department in } \\
\text { cooperation with various } \\
\text { offices, including the } \\
\text { Institutional Research and } \\
\text { Planning Office }\end{array}$ & $\begin{array}{l}\text { Various systems, including } \\
\text { Business Objects and others }\end{array}$ \\
\hline
\end{tabular}


A complex picture emerges from this mapping of custodians and systems for the management and use of RRI in the six SA universities interviewed for this chapter, from which we can make a number of observations.

Firstly, although the research support office plays a key role in most instances, it is by no means the only role player and/or stakeholder. Excellent cooperation with a range of other role players in the institution is not only crucially important, it is a sine qua non for the effective management and use of RRI. Ideally the different role players involved with RRI in an institution need to form a "community of practice", that is, a group of people "bound together by a shared passion and a passion for a joined enterprise" to solve problems, to transfer best practices, and to develop professional skills (Wenger and Snyder, 2000:139). Such communities can break down silos and develop breakthrough innovations.

Secondly, it transpires that certain types of information and certain uses (e.g. the last five types or RRI listed in Table 1) involve a greater number of role players.

Thirdly, different methods of research information management are in use, including home grown systems as well as vendor components which are used within their existing (legacy) systems to support research. There is evidence also of independent systems and contractors customising frameworks and utility software to build research support applications (cf. Bonig 2012:3).

Fourthly, the universities surveyed for this study often use more than one research administration and management system.

Fifthly, research management and administration systems are becoming more important because of increased audit and oversight requirements. Grants and contracts increasingly include items such as network and digital storage security and, with growing volumes of sponsored research, the administrative burdens also increase. Bonig (2012:4) states that in such circumstances automated systems are required to manage and control information requirements.

Finally, the South African universities that we have surveyed use at least three systems that are internationally popular, namely, Oracle PeopleSoft Solutions, InfoEd and Kuali Coeus. The international offerings deemed by Bonig (2012) as, however, the most important ones, such as Romeo (by Process Pathways), Grants Modules (by Oracle PeopleSoft Solutions), Campus Platform for RMAS (by Agresso), SAP Research Solutions, Banner (by Ellucian), Click Portal and Ideate, are not used by the South African universities surveyed for this study. This is partly because of the high cost of these systems.

The unfolding events related to the use of InfoEd by South African universities calls for more elaboration. InfoEd is an American research information management system that provides a single solution for the integrated management of proposals, protocols, patents, publications and profiles, including a back office tool for managing applications and submissions, a system that enables researchers to apply online for funding, ethical clearance, and to track the progress of applications, a CV portal that will be integrated with South Africa's National Research Foundation's (NRF) Online System, and a reporting tool for government departments. 
In 2007, at the behest of the Department of Science and Technology (DST), a national consortium was formed, the South African Research Information Management System project (SA RIMS) consisting of 22 universities and nine Science Councils. The DST required a single platform for reporting on its investments in research and development to publicly funded higher education institutions and research councils, particularly to inform strategic decision making. Its secondary aim was to provide a common platform for such institutions to support their research management processes, and thus build national research management capacity. The DST, after considerable negotiation with the publicly funded institutions, purchased a country license for the InfoEd system. This is managed on behalf of the DST by the NRF. It is thus a national system implementation. It has, however, met with limited success. By 2015, InfoEd was used by some of the institutions surveyed for this study and then only on a limited scale. Not one of the respondent institutions uses the system in an integrated manner. The trend is to use some of the modules together with internal legacy systems. These institutions invest in the development of their legacy systems to ensure effective integration with InfoEd. It remains to be seen whether the ambitious South African initiative to customise InfoEd for local needs will succeed.

Having discussed the complexities of curatorship of RRI, we now focus on what levels of organisational intelligence the RRI activities fall into.

\section{Research-related information as organisational intelligence}

Our insight into the management and use of RRI in South African universities can be enriched by categorising these in terms of Terenzini's $(1993,2013)$ three tiers of organisational intelligence (the three tiers are succinctly described in Chapter 1).

\section{Technical or analytical intelligence}

Research support offices capture and analyse factual information related to research activities such as research outputs, contracts, applications for ethics clearance, demographics of researchers and postgraduate students, applications for funding, etc. The information is used as technical or analytical intelligence. It requires familiarity with the standard categories of information, the definitions of technical terms, the rules and formulae required for reporting purposes, knowledge of the indicators used to measure research performance, and analytical and methodological skills and competencies. The uses of RRI as technical or analytical intelligence reported by the six South African universities under investigation also includes statutory reporting (the annual submission of research outputs to the Department of Higher Education and Training (DHET) for subsidy purposes) (see Chapter 10) and institutional reporting for a wide range of purposes.

\section{Issues intelligence}

Research managers are expected to provide intelligence that can be used to address substantive issues in universities. The research directors interviewed for this study highlighted information needs related to decision-making on resource allocation and budgeting for research, research policy-making processes, operational processes related to 
the development and support of research, and decision-making related to directed research initiatives and rewards based on appropriate indicators. Research managers therefore need to have excellent knowledge of institutional goals, of the budgeting process and of institutional structures and systems. They also need to have a good general knowledge of the functioning of the institution, its areas of strengths and emerging competencies and opportunities related to the institution's research function.

\section{Contextual intelligence}

Research managers need to understand the higher education culture in general, the national and international HE environments and the trends and developments in the field. Our interviewees emphasised that there is a strong focus on social impact and a need for institutions to show that they are contributing to national and international strategies, such as the South African National Development Plan and the global Sustainable Development Goals. Research for the benefit of society is a clear objective. Interviewees emphasised the importance of communicating research results and successes to different audiences and noted that this requires different approaches for both reporting and for creating visibility of the research-related activities of the institution.

To summarise then, the technical and analytical intelligence generated from RRI is used for external and internal reporting of factual information. It forms the basis of the other two (higher) levels of uses of RRI. The more advanced levels of organisational intelligence require higher levels of integration of RRI as was gathered from the interviews.

\section{Uses of research-related information}

In this section we report on the uses of RRI, as provided by the research directors that we interviewed. We distinguish between four main uses, namely, to report on research performance, to support evidence-based policy- and decision-making, to raise the visibility of research (including science communication) and to enhance directed research support.

\section{Innovative reporting of research performance}

Prompted by the changing nature of the HE landscape characterised, inter alia, by tough competition amongst institutions for scarce resources and the drive for greater recognition and higher reputation, institutional researchers in research support offices are using innovative ways to report the research performance of their institutions. Different audiences require different types of reporting - a report to Senate, for example, looks different to a report for individual departments and faculties or a report to external audiences. Interpreted, integrated, holistic and contextualised information is expected, attractively and accessibly presented, with well-considered recommendations. It is not sufficient simply to provide tables with data. Information graphics and innovative forms of data visualisation are expected. 


\section{Using research-related information in support of evidence-based decision making}

$\mathrm{RRI}$ is widely used in evidence-based decision making. Respondents mention three specific decision-making contexts, namely decisions on research policy, strategic decisions on specific initiatives and decisions related to operational processes and planning.

\section{Using research-related information to inform policy development}

The development of research policies is usually informed by RRI and often the expertise of institutional researchers in research support offices is enlisted in policy-making processes. Their role varies from the provision of information to the drafting of research-related policies.

“... in terms of research-related processes and policies...we are instrumental in those. From time to time we are involved in drafting policies that will advance our position in terms of research. Examples of that would be research ethics, plagiarism, conflict of interest, policies on consultation work, full costing of research, indirect cost delivery, postdoctoral policy, and so forth. So over the past years I've probably every year been involved in the development of two to three research-related policies or revising policies and the processes that go with that."

(Interview 4)

\section{Using research-related information to inform research-related strategies}

There is evidence that strategic decision-making is informed by RRI. The information is sometimes used upfront to guide and inform strategic decisions, and sometimes to back up elements of strategy already decided upon.

“... it always starts with the strategy of the university. And the way they [the Business Intelligence Unit] package their data is in response to the strategy of the university. So the current strategy calls for $x, y, z$ key strategic areas ... and so in each of those strategic areas, they will pull together the necessary data to inform that strategy ... that strategic objective."

(Interview 1)

"With the new strategy that the university introduced and implemented since 2012, the key performance areas for the academics include... bringing in external income, supervising students and publishing ... and we could use the RRI to provide to the executive information on human resources ... to try and come up with a normal and appropriate type of system for remuneration and rewards."

(Interview 5)

Not all directors are, however, equally satisfied with their role in strategic decision-making processes:

"I have often been worried that we don't have enough influence on the broad strategic direction of the university. And I'll be frank about it that, I think we as a division could make a much bigger contribution to the overall strategy, but I think we sometimes see strategies being developed without having had a real input into shaping them. I know that from the bottom up we facilitate a lot of lobbying and make some noise sometimes which influences strategy, especially in the 
environment of the deputy vice-chancellor for research, we can certainly make a big impact. But sometimes the strategy is being imposed from the top and there is not enough consultation with the likes of ourselves and the researchers in the faculties specifically."

(Interview 4)

There is an expectation that the institutional researchers in research support offices are well informed about research-related strategies in their respective institutions and that they are knowledgeable and able to make inputs in strategic decision-making processes.

"... our involvement in the research committee means that we have to also work on the research strategy of the university. So we need to have a good understanding of our strengths and emerging areas ... where our niche areas lie and what makes us unique. Although there is not a structured way in which we capture the information, I think this office tries to build up a very good understanding of what is happening..."

(Interview 4)

\section{Using research-related information in support of operational processes and planning}

Since research support offices are closely involved in the implementation and execution of research-related policies and strategies, they are expected to provide the necessary information and expert advice to set up the relevant institutional processes and systems and to ensure their smooth running. The planning, monitoring and evaluation processes at various levels in universities are information intensive. In response, research support offices provide customised RRI on the performance of each department, school or faculty.

“... (the information pack) ... I think it adds an enormous amount of value at departmental and faculty planning level... and that's the kind of feedback we also received from our departmental chairs and deans, in that it came at the right time for them to really use that information in their budgeting and planning for the next three years. So ... that's probably the biggest value it adds ... we want our faculties and departments to make informed decisions." (Interview 4)

\section{Raising the visibility of research for impact and relevance}

All the research directors emphasised the extreme importance of communicating researchrelated activities effectively. This has developed into a specialised focus area in the work of research support offices and it is usually done in cooperation with the university's marketing and communication departments. In many cases faculties/schools and even departments appoint dedicated communication officials. Their communication activities rely heavily on the RRI generated by institutional researchers located in research support offices.

\section{Science Communication}

A sub-set of effective research reporting and communicating is the growing area of science communication. Public science communication can be broadly understood as the efforts to make information about science, including issues in science that have moral, legal and ethical implications, more relevant, accessible and meaningful to society. It also encourages dialogue between scientists and diverse public and policy audiences. 
The "science of science communication" encourages scientists to become more scientific in their approach towards, and practice of, public communication and engagement. It emphasises the importance of a deeper understanding of how people learn about and respond to science, and how contextual factors and new media environments influence public science engagement. The science of science communication has four tasks: to identify the science most relevant to the decisions that people face, to determine what people already know, to design communications to fill the critical gaps (between what people know and need to know) and to evaluate the adequacy of those communications (Scheufele 2013).

Institutional researchers in research support offices are increasingly involved in these tasks. Research directors emphasise the critical importance of raising the visibility of research and demonstrating the relevance and significance of the research conducted at research institutions. Although these IR professionals do not necessarily themselves write articles for the various external audiences (although sometimes they do), they can make a significant contribution to the effective public communication of science and the societal responsiveness of the research institutions where they work. They do this by providing relevant and timely information to communication staff or directly to other stakeholders. They add value to the information through their interpretations and explanations in the light of the contextual intelligence available to them. Examples include the communication of new developments in the research portfolio of the university, new technologies that have been developed, awards and prizes received by researchers, profiles of top researchers, Centres of Excellence and Research Chairs awarded, research-related facts and statistics and stories about completed research. They may also communicate outcomes of research projects that can lead to policy development and interventions aimed at development and the enhancement of the quality of life.

An example of an initiative driven by a research office is the development of a Knowledge Directory. This is an e-platform making information about the expertise of the researchers in the institution more widely accessible by means of a web console featured on the institution's website.

"Of course, other universities ... international universities included, would want to see where we can potentially collaborate ... So both the Knowledge Directory as well as the research report would serve that purpose of increasing networks ... increasing visibility of our research."

(Interview 4)

\section{The research report in a new format}

It is a statutory requirement that institutions must annually submit a list of research outputs produced in a particular year to the DHET. Traditionally this was known as the annual research report and it consisted only of a list of publications. Although it is necessary for reporting and subsidy purposes, such a report does not make interesting reading. Institutions have in recent years drastically changed the format and contents of their annual research reports into attractive, colourful and reader-friendly publications, which are usually digitally available: 
“... the annual research report ... is really a publication that showcases the effect and the contribution and the impact of our research. So ... it tells a story. And I think that is important. It covers all those different types of research information we referred to. Of course we also give some of the statistics there, to indicate performance ... we make it accessible to different audiences, external and internal, publicising and showing the impact of our research." (Interview 4)

\section{Enhancing directed research support}

RRI is used to plan, design and offer well-directed and appropriate research-support opportunities, including opportunities for funding, research collaboration, and capacity building and skills development.

\section{Communicating support available to researchers}

Communication for this purpose is done by means of information sessions to researchers and through websites, newsletters and listservs, using e-mail addresses of all researchers on campus.

One such example is the use of an electronic platform called the Researcher Persona, developed by one of the universities:

"What we have found is that we [in the Research Support Office] know the policies and the processes and the procedures, but for a new researcher, for example, it's an absolute maze of information, and they don't know where it all sits. So the Researcher Persona is to try to repackage what is sitting somewhere on the website, but in many different places. Now we try to provide them with a package of information that they can click on, and they find all the researchrelated policies that they need to know about ... opportunities for them to help to do their research, training opportunities spread across our division, the library and information services, IT, the language centre, everywhere. So we try to repackage existing things to make it more easily accessible for our researchers (on an online web-based platform)."

(Interview 4)

\section{Planning and executing directed interventions}

Research support offices provide the support to develop and broaden the research portfolio of their universities. Research directors explain that their institutional researchers use RRI to develop creative new ways to support research activities, to direct new initiatives, to decide on interventions to enhance research productivity and quality, and to monitor and award research performance.

Examples of such initiatives include (a) the development of mentorship programmes for emerging researchers based on information such as age (young researchers), experience (number of years since completion of PhD), qualifications (e.g. researchers without a PhD) and fields of study; (b) strategic initiatives to increase the university's postdoctoral research corps; (c) the provision of research incentives to academic staff members based on their research productivity and number of Masters and doctoral graduates delivered; and (d) the 
establishment of new and the broadening of existing partnerships with other universities, for example other African universities, through information on current collaborations and co-publications.

“... our aspirations for the internalisation of our research ... ultimately we would try to strengthen our links into Africa, but not lose the good connections that we already have with many strong institutions in the global North. So the ideal now for us would be to identify and support three-way partnerships ... for research collaboration and collaborative postgraduate training ... so we need to identify and find hotspots of research ... where people are already collaborating ... and you usually identify that by looking at co-authored publications. So that is where we use our data at the moment, to try and identify those hotspots." (Interview 6)

To summarise this section, RRI is used for a wide range of purposes, including but going beyond traditional mandatory reporting. Institutional research is needed to enrich and transform the basic data into different forms of intelligence so that the information is useful for all the new uses discussed in this section.

\section{Enabling the generation of value-added research-related information}

The increasingly wide range of uses of RRI enables new forms of collaboration and the development of new skills.

\section{Institutional collaboration}

Research directors emphasise that internal institutional collaboration is essential for recording and integrated reporting purposes. The respondents all commented on the negative implications of different sections in the university working in silos and how that hinders integrated reporting. Research directors are committed to enhancing collaboration between offices such as the Library, Marketing \& Communication, Community Engagement, Information and Communication Technology, Finance, Human Resources, the Registrar's Office, and the Institutional Research and Planning Office so that holistic, interpreted and contextualised information can be provided.

“... we have different departments looking after ... or different divisions looking after different types of RRI. And then we have faculties sitting on some information. And I think what we have recognised as one of our biggest challenges over the past years ... there is no quick solution for it ... is to try to integrate, through using systems ... if you really want to have a broad overview of research ... taking into consideration all the different categories ... then you have to go and look in many different places."

(Interview 3)

\section{Skills and experience required from institutional researchers in the research support office}

The need for integrated and interpreted information requires new skills of the staff of the research support office. Research directors report the increased use of advanced technologies 
and research information management systems to enable more advanced and integrated reporting. This requires new technical (databases, warehouses, business intelligence), analytical and interpretation skills. Research support offices increasingly consult or employ experts such as business analysts, legal experts and data analysts to cater for the demand for RRI transformed into different forms of intelligence.

Furthermore, science communication is a relatively new area in research management and it requires writing skills, knowledge of the field of research, uptake and utilisation, and how to engage with the media.

The greater need for integrated RRI to inform value-added decision making also requires more advanced analytical and interpretation skills. Research directors noted that an understanding of the research process itself is a great advantage for institutional researchers and research managers.

From the interviews with research directors, it was also noted that apart from special skills required, one should not underestimate the value of institutional memory gained by individuals who have worked in a particular institution and within a particular research support office for a long time. Institutional memory of experienced staff members is seen as an extremely important source of research-related information.

"It just brings a special kind of dimension to your service that you can provide a researcher if you really understand how research works ... and understand the research process. And I think that's why we have, particularly in the more senior positions in this office, we try to recruit people who have been through the research process themselves, because quite a bit of what we do is ... could be seen as administrative ... but a lot of ... increasingly what we do is being seen as really providing an enabling environment and facilitating processes rather than just following strict admin rules."

(Interview 4)

Research directors also agree that apart from skills and experience, one needs a team of dedicated, enthusiastic and knowledgeable staff members if one wants to cater for the focus on providing value-added research-related information:

"I think if you've got the staff that actually understands their supportive, facilitating role in relation to the actual researchers ... I think you have won half the struggle. And then ... building up that knowledge, that institutional knowledge, longer term knowledge and knowing people and knowing their work ..." (Interview 2)

There are thus a number of possibilities for skills development for RO staff. Data analysis, legal understanding, writing and communication, and a good understanding of, if not actual experience in, the research process itself.

\section{Inter-institutional cooperation between research support offices}

Cooperation between research support offices in different universities has become essential. Although there is competition between institutions, there is a general recognition that sharing best practices and even the sharing (of certain types of) RRI is in everyone's interest. 
For example, benchmarking information is necessary to identify a university's competitive edge or to decide where to re-focus or redirect existing research efforts.

"It's really vital because we're a small science system in South Africa. And I think we can achieve so much more if we work together. So it's ... of course, you know, academics are always competitive. Universities are competitive by definition. So I guess it's about maintaining that balance ... from where I'm sitting on the management side, I truly believe in the value of collaboration and partnerships at all levels. And that would include sharing good practice, working together to improve things, so that ultimately we can have a better voice globally, for the continent ... for Africa."

(Interview 5)

"We are constantly benchmarking our research outputs with our top competitors ... and that is where I'm also focusing strategically, is that we want to develop more partnerships with other universities ... I find there is an excellent congeniality between research offices. Although there is a kind of competitiveness ... it's very open."

(Interview 2)

In this section we briefly looked at how value-added research information could be generated, through the mechanisms of internal institutional collaboration, the development of appropriate skills of research management staff, and, finally, through inter-institutional cooperation.

\section{Findings and conclusions}

We have argued and demonstrated that the management and use of RRI should be seen as part of the broader IR activities of universities and that research support offices are custodians and providers of a host of information that is critical for institutional decisionmaking. IR practitioners based in research support offices are increasingly playing an active and visionary role in developing strategy and assessing the long-term positioning for institutions. Research support offices have experts who function as institutional researchers in that these individuals extract, analyse and disseminate data, with a specific focus on RRI.

The changing landscape of HE and the broad range of uses of RRI require a more advanced and integrated approach to the generation, interpretation and communication of this type of information. RRI has to be transformed into all three forms of organisational intelligence identified by Terenzini. The higher levels of intelligence (issues intelligence and contextual intelligence) require competence in the generation and use of the basic forms of analytical intelligence. The higher the level (issues/context), the more complex the collection of information becomes and the more co-ordinated and integrated it is required to be.

The need for a more holistic, integrated approach to RRI requires new forms of organisation of information according to specific audiences and needs, more co-operation between research support offices that generate information, greater communication of research results through innovative ways, and new skills and competencies by research managers. Apart from meeting reporting obligations, research support offices also inform institutional performance management through the provision of data that inform performance 
indicators. They support and participate actively in research-related strategy development and decision making and they make a major contribution to further the research standing of their institutions by identifying and supporting strategic initiatives to enhance research excellence. This, in the end, leads to more effective operations and contributes to the strategic positioning of institutions and national knowledge systems in a global context.

\section{References}

Altbach, P., Reisberg, L. \& Rumbley, L.E. 2010. Tracking a Global Academic Revolution. Change 42(2):30-39. http://dx.doi. org/10.1080/00091381003590845

Bonig, R., 2012. Strong field of RM\&A systems for education puts onus on institutions to search deep and wide. [Online]. Available: https://www.gartner.com/ doc/2145715/strong-field-rma-systemseducation [2016, June 1].

Calderon, A.J. \& Webber, K.L. 2015. Institutional research, planning and decision support in Higher Education today, in A. J. Calderon \& K. L. Webber (eds.). Institutional Research and Planning in Higher Education: Global Contexts and Themes. Routledge. 4-15.

Carter, I. \& Langley, D. 2009. Overview of research management and administration. Perspectives: Policy and practice in Higher Education 13(2): 31-32. http://dx.doi. org/10.1080/13603100902805359

Chirikov, I. 2013. Research universities as knowledge networks: the role of institutional research. Studies in Higher Education 38(3):456-469. http://dx.doi. org/10.1080/03075079.2013.773778

Deem, R. 2010. 'Herding the academic cats: The challenges of "managing" academic research in the contemporary UK university'. Perspectices: Policy and Practice in Higher Education 14(2):37-43. http://dx.doi. org/10.1080/13603101003776127

Fumasoli, T. \& Huisman, J. 2013. Strategic Agency and System Diversity: Conceptualizing Institutional Positioning in Higher Education. Minerva, 51:155-169. http://dx.doi.org/10.1007/ s11024-013-9225-y

Hazelkorn, E., 2015. Rankings and the reshaping of higher education. The battle for world class excellence. New
York: Palgrave Macmillan. http://dx.doi. org/10.1057/9781137446671

Kehm, B.M., 2015. Higher Education as a Field of Study and Research in Europe. European Journal of Education 50(1):60-74. http://dx.doi.org/10.1111/ ejed. 12100

Langley, D., \& Ofosu, M.H. 2007. Celebrating a Profession: The Global Perspective. The Journal of Research Administration 38(1):39-43.

Lourens, A. 2012. Shaping the research agenda - A focused approach. Unpublished presentation for a Southern Africa Research and Innovation Management Association. Workshop of the Southern African Research and Innovation Management Association (SARIMA). Potchefstroom: North-West University.

Reichard, D.J., 2012. The History of Institutional Research. In R. D. Howard, G. W. McLaughlin, \& William E. Knight, eds. The Handbook of Institutional Research. San Francisco, pp. 3-22.

Research Africa. 2013. Being a research manager. Understanding your role and maximising your impact. Notes for researchers and research managers $A$ Research Manager's Notebook. Series produced under the RIMI4AC Project funded by the European Commission's Africa, Caribbean and Pacific Science and Technology Programme.

Scheufele, D.A. 2013. Communicating Science in Social Settings. Proceedings of the National Academy of Sciences 110 (supplement 3, August 20 2013). http:// dx.doi.org/10.1073/pnas.1213275110

Schützenmeiser, F. 2010. University Research Management: An exploratory Literature Review. Institute of European Studies. [Online]. Available: http://escholarship. org/uc/item/77p3j2hr. [2016, June 14]. 
Shelley, L. 2010. Research Managers Uncovered: Changing Roles and 'Shifting Arenas' in the Academy. Higher Education Quarterly 64(1):4164. http://dx.doi.org/10.1111/j.14682273.2009.00429.x

Terenzini, P.T. 1993. On the nature of institutional research and the knowledge and skills requires. Research in Higher Education 34(1):1-10. http://dx.doi. org/10.1007/BF00991859

Terenzini, P.T. 2013. "On the Nature of Institutional Research" Revisited: Plus ca Change...? Research in Higher Education 54(2):137-148. http://dx.doi. org/10.1007/s11162-012-9274-3

The Association of Commonwealth Universities. 2015. Managing researchrelated information in African Universities. [Online]. Available: https://www.acu.ac.uk/publication/ download?id=541 [2016, June 14].

Theron, T. 2013. Research management. Southern African Research and Innovation Management Association (SARIMA), Cape Town, 8-9 July 2013.

Volkwein, J.F. 2008. The Foundations and Evolution of Institutional Research. New Directions for Higher Education 141:5-17. http://dx.doi.org/10.1002/ he. 289

Volkwein, J.F., Liu, Y. \& Woodell, J. 2012. The structure and functions of institutional research offices, in R. D. Howard, G. W. McLaughlin, \& William E. Knight (eds.). The Handbook of Institutional Research. San Francisco: Jossey-Bass. 22-39.

Wenger, E.C. \& Snyder, W.M. 2000. Communities of practice. The organizational frontier. Harvard Business Review January-February:139-145.

Whitchurch, C. 2007. The changing roles and identities of professional managers in UK higher education. Perspectices: Policy and Practice in Higher Education 11(2):53-60. http://dx.doi. org/10.1080/13603100701259022

Whitchurch, C. 2008. Shifting identities and blurring boundaries: The emergence of third space professionals in UK higher education. Higher Education Quarterly 62(4):377-396. http://dx.doi. org/10.1111/j.1468-2273.2008.00387.x

Whitchurch, C. 2009. The rise of the blended professional in higher education: a comparison between the United Kingdom, Australia and the United States. Higher Education 58(3):407-418. http://dx.doi.org/10.1007/s10734-0099202-4

Whitchurch, C. 2013. Reconstructing Identities in Higher Education. The Rise of Third Space Professionals. Society for Research into Higher Education (SHRE). Routledge. 